Addendum

\title{
Addendum: de Leve, S.; et al. The CD73/Ado System-A New Player in RT Induced Adverse Late Effects. Cancers 2019, 11, 1578
}

\author{
Simone de Leve, Florian Wirsdörfer and Verena Jendrossek * (i) \\ Institute of Cell Biology (Cancer Research), University Hospital Essen, 45122 Essen, Germany; \\ simone.deleve@uk-essen.de (S.d.L.); florian.wirsdoerfer@uk-essen.de (F.W.) \\ * Correspondence: verena.jendrossek@uni-due.de; Tel.: +49-201-7233380; Fax: +49-201-7235904
}

Received: 20 November 2019; Accepted: 22 November 2019; Published: 28 November 2019

The authors would like to make an addendum to their published paper [1].

There was a missing annotation and reference in the original version of the article in the caption of Figure 1 in [1]:

The authors wish to mention that some elements from Figure 1 are inspired from Salmi and Jalkanen [2] and modified from Cappuccini, "Radiation-induced pneumonitis and fibrosis-Defining the role of immune cells and regulatory molecules" (Ph.D. thesis) [3].

The changes do not affect the scientific results.

The rest of the manuscript does not need to be changed. The authors would like to apologize for any inconvenience caused.

\section{References}

1. De Leve, S.; Wirsdorfer, F.; Jendrossek, V. The CD73/Ado System-A New Player in RT Induced Adverse Late Effects. Cancers 2019, 11, 1578. [CrossRef] [PubMed]

2. Salmi, M.; Jalkanen, S. Cell-surface enzymes in control of leukocyte trafficking. Nat. Rev. Immunol. 2005, 5, 760-771. [CrossRef] [PubMed]

3. Cappuccini, F. Radiation-induced pneumonitis and fibrosis-Defining the role of immune cells and regulatory molecules. Ph.D. Thesis, University Duisburg-Essen, Essen, Germany, 2017.

(C) 2019 by the authors. Licensee MDPI, Basel, Switzerland. This article is an open access article distributed under the terms and conditions of the Creative Commons Attribution (CC BY) license (http://creativecommons.org/licenses/by/4.0/). 